\title{
Ecological Characterization of Elaeis guineensis Jacq. Agroforestry Parklands in the Cacheu Region (Guinea Bissau)
}

\author{
Boubacar Sagna $^{1,3}$, Daouda Ngom ${ }^{2}$, Boubacar Camara ${ }^{1}$, Antoine Sambou ${ }^{1}$, \\ Mamadou Abdoul Ader Diedhiou', Mamadou Goudiaby ${ }^{4}$, Abdou Seydou Mane ${ }^{3}$, Yvan Le Coq ${ }^{3}$ \\ ${ }^{1}$ Department of Agroforestry, Assane SECK University of Ziguinchor, Ziguinchor, Senegal \\ ${ }^{2}$ Department of vegetable Biology, Cheikh Anta Diop University, Dakar, Senegal \\ ${ }^{3}$ Research and Development Group for Rural Development (Grdr), Cacheu, Guinea Bissau \\ ${ }^{4}$ Regional Inspectorate for Water and Forests, Hunting and Soil Conservation of Ziguinchor, Ziguinchor, Senegal
}

Email address:

boubacarsagna22@gmail.com(B. Sagna), daoudangom52@gmail.com(D. Ngom), camarabouba2@gmail.com(B. Camara), tonysambouegos@yahoo.fr(A. Sambou), abdoulader28@gmail.com(M. A. A. Diedhiou), alaminegoudiaby@gmail.com(M. Goudiaby), abdou.mane@grdr.org(A. S. Mane), yvan.lecoq@grdr.org(Y. L. Coq)

\section{To cite this article:}

Boubacar Sagna, Daouda Ngom, Boubacar Camara, Antoine Sambou, Mamadou Abdoul Ader Diedhiou, Mamadou Goudiaby, Abdou Seydou Mane, Yvan Le Coq. Ecological Characterization of Elaeis guineensis Jacq. Agroforestry Parklands in the Cacheu Region (Guinea Bissau). American Journal of Agriculture and Forestry. Vol. 7, No. 6, 2019, pp. 321-329. doi: 10.11648/j.ajaf.20190706.22

Received: September 19, 2019; Accepted: December 5, 2019; Published: December 16, 2019

\begin{abstract}
Elaeis guineensis Jacq is a species of palm commonly called oil palm. It is a source of many products and services. It is used in agroforestry systems. The Elaeis guineensis Jacq parklands or palm groves occupy an important place in the livelihoods of the local population of Guinea Bissau especially in the region of Cacheu where important natural formations were found. However, despite the socio-economic importance of these parklands, their dynamics in the region have been poorly studied. It is in this context that the present study was initiated with the objective of evaluating the current state of the Elaeis guineensis parklands in the region through an ecological characterization. To this end, 90 vegetation surveys of $2500 \mathrm{~m}^{2}$ were carried out in six villages in three sectors of the region, for a total area of $22.5 \mathrm{ha}$. These surveys revealed a high floristic diversity in the Elaeis guineensis parks in the region. Thus, 75 species divided into 63 genera belonging to 25 families were registered. The parklands are also characterized by a high density of Elaeis guineensis with 775 individuals / ha and $90 \%$ of which consist of young plants that often do not reach adulthood. In addition to the difficulties associated with poor recruitment of regeneration, populations of Elaeis guineensis are under heavy human pressure in the area. The mortality rate and the anthropization index, which are respectively $15.97 \%$ and $23.35 \%$. These combined factors reveal a certain fragility of the Elaeis guineensis parklands in the Cacheu region. Hence the need to make the inventory that is a prerequisite for any strategy of recovery and sustainable exploitation of the species in order to sustain these production systems.
\end{abstract}

Keywords: Agroforestry, Elaeis Guineensis, Parklands, Ecological Characterization

\section{Introduction}

Guinea Bissau has an significant potential of natural resources, particularly forest resources [4]. The forest plays an important function in the livelihoods of the local population. Among the forest species existing in the area, Elaeis guineensis is one of the most exploited for its many services and products such as palm oil, palm kernel oil, wine, building materials, medicines, soap, fertilizers, etc. This is an oilseed plant native to the tropical forests of Central Africa around the Gulf of Guinea [17]. It evolves considerably in environments with relatively high rainfall such as Guinea Bissau where important natural palm tree formations are found, especially in the Cacheu region located in the northwest of the country [5]. In this region, palm oil production and palm wine production are income-generating activities for rural families, particularly for young and female 
producers. Apart from its economic value, palm oil has nutritional and/or medicinal values because of its high content of vitamins A and E [7].

However, despite its socio-economic importance, the dynamics of palm groves are not well studied. Thus, the overall objective of this study is to contribute to the assessment of the current state of the $\mathrm{t}$ Elaeis guineensis parklands in the Cacheu region through ecological characterization. This specifically involves determining the floristic composition and establishing the vertical and horizontal structures and structural parameters of the Elaeis guineensis parklands.

\section{Methodological Approach}

\subsection{Presentation of the Study Area}

Cacheu is a region of Guinea-Bissau located in the northwest of the country. It borders Casamance (Senegal) in the north, the Atlantic Ocean in the west, the Biombo region in the south and the Oio region in the east. It is divided into six (6) sectors: Bigene, Bula, Cacheu, Caió, Canchungo and Sao Domingos. As part of this study, a sample of six villages in the three richest palm grove areas was selected. These are the villages of Bucucucur and Bnokly in Cacheu sector, Mpakaque and Djita Centro in Canchungo sector and Ponta Campo and Ponta Pedra in Caio sector (Figure 1).

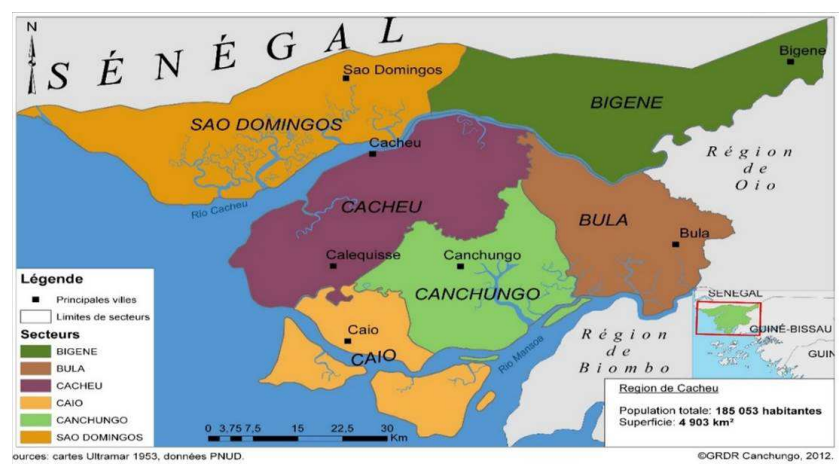

Figure 1. Administrative subdivision of the Cacheu region.

\subsection{Vegetation Surveys}

The choice of the villages was made on the basis of accessibility. Thus, in each of the sectors, a landlocked village and an easily accessible village were chosen. A total of 15 square plots of $50 \mathrm{~m}$ in length $\left(25500 \mathrm{~m}^{2}\right)$ in the parklands of each village. These dimensions are those used by [8] and repeated by $[10,7,24]$ for the forest inventory in agroforestry parks. In sites where parks are located on different landscape units (plateau, slope or even rice field), plots have been placed according to the toposequence. In order to assess the current state of Elaeis guineensis parklands, 90 vegetation surveys were carried out in six villages in three sectors of the Cacheu region. These made it possible to identify a number of qualitative and quantitative parameters of palm trees. The quantitative parameters concern dendrometric data such as: the diameter at breast height (dbh), measured at $1.30 \mathrm{~m}$ using a forestry calliper, which made it possible to calculate the basal area and establish the horizontal structure of the stand. The crown diameters in two directions (in two directions (North-South and East-West) were measured for the assessment of the canopy cover. To establish the vertical structure, the height of the trees was measured using a Blum less dendrometer.

Qualitative parameters, on the other hand, refer to the estimation of regeneration and the identification of dead subjects or those who have suffered damage due to human activities. Damage is considered to be any human action that may cause nuisance to individuals in the stand. The individuals taken into account are either cut, debarked, pruned or with traces of fire, etc. [7].

\subsection{Data Processing and Analysis}

Vegetation survey data were processed using the Excel spreadsheet, which was also used to develop graphs and classify numerical data. It was also used to calculate the parameters for characterizing park vegetation. Software such as R. version 3.4 .2 (2017-09-28) and XLSTAT were also used to calculate certain parameters and to perform multivariate analyses such as Main Component Analysis. The following formulas will be used to calculate these parameters:

a) Specific richness

It was evaluated on the basis of total specific wealth and average specific wealth. Total species richness $(\mathrm{S})$ is the total number of species in the stand considered in a given ecosystem [23]. The average specific richness is the average number of species per survey for a given sample [18].

b) Frequency Analysis

Frequency analysis is a method of assessing the distribution of species through surveys. The frequency of presence provides information on the distribution of a species in a stand. It is expressed in \%, and is estimated by the following formula [20]. cited by [20].

$$
\mathrm{F}=\frac{\mathrm{Nri}}{\mathrm{Nr}} \times 100
$$

$\mathrm{F}=$ frequency of presence expressed as a percentage (\%); $\mathrm{Nri}=$ number of records where species $\mathrm{i}$ is found and $\mathrm{Nr}=$ total number of records.

c) The density

Density is the number of individuals per unit area. It is expressed in number of individuals/ha. It is obtained by dividing the total number of individuals in the sample by the area sampled.

$$
\text { Dob. }=\frac{\mathrm{N}}{\mathrm{S}}
$$

Dob=Observed density $\mathrm{N}=$ total number of individuals in the sample considered and $\mathrm{S}=$ sample area in ha.

d) Shannon's Diversity Index

The Shannon index makes it possible to express diversity by taking into account the number of species and the abundance of individuals within each of these species. The 
Shannon-Wiener index is the most commonly used and is recommended by various authors [14]. It is given by the following formula:

$$
H^{\prime}=-\sum_{i=1}^{s} P i \log P i
$$

pi=proportional abundance or percentage of species importance: $\mathrm{pi}=\mathrm{ni} / \mathrm{N} ; \mathrm{ni}=$ number of individuals of a species in the sample; $\mathrm{N}=$ total number of individuals of all species in the sample.

$\log =\log$ base 2

e) The Pielou Evenness Index

The equity index measures the distribution of individuals within species, regardless of specific wealth. Its value varies from 0 (dominance of one of the species) to 1 (even distribution of individuals in the species) [13]. It is given by the following formula:

$$
\mathrm{J}^{\prime}=\mathrm{H}^{\prime} / \mathrm{H}^{\prime} \max
$$

$\mathrm{H}^{\prime} \max =\log \mathrm{S}(\mathrm{S}=$ total number of species)

f) The basal area

Basal basal area or basal coverage refers to the area of the tree evaluated at the base of the tree trunk. It is expressed in square metres per hectare $\left(\mathrm{m}^{2}\right.$.ha.-1). It is therefore obtained from the following formula

$$
S t=\frac{\sum \pi\left(\frac{d_{1.3}}{2}\right) 2}{S_{E}}
$$

$\mathrm{St}=$ basal area; $\mathrm{d} 1.3=$ diameter at $1.3 \mathrm{~m} ; \mathrm{SE}=$ area of the sample considered in ha.

g) The stand regeneration rate (SRR)

It is given by the percentage ratio between the total number of young plants and the total number of stands [21]. In this study, for the species Elaeis guineensis and Borassusakeassii, individuals with stipes less than $1.30 \mathrm{~m}$ high are considered to be part of regeneration [21].

$$
\text { SRR }=\frac{\text { Total number of young plantsy }}{\text { Total population size }} \times 100
$$

The total population size includes both young and adult plants.

h) The specific importance of regeneration (SIR)

It is obtained from the percentage ratio between the number of young plants of a species and the total number of young plants counted [1]

$$
\text { SIR }=\frac{\text { Number of young plants of one species }}{\text { Total number of young plants enumerated }} \times 100
$$

i) The mortality rate

The mortality rate is the percentage of the number of individuals who die in the stand. It is obtained by multiplying by 100 the ratio between the number of dead individuals $(\mathrm{Nm})$ and the total number of individuals in the stand $(\mathrm{Nt})$. It is calculated according to the formula:

$$
\text { Mortality rate }=\left(\frac{\mathrm{Nm}}{\mathrm{Nt}}\right) \times 100
$$

$\mathrm{Nm}=$ Total number of dead individuals

$\mathrm{Nt}=$ Total number of individuals

\section{Results}

\subsection{Floristic Composition of the Elaeis guineensis Parklands}

Vegetation surveys carried out have shown that Elaeis guineensis agroforestry parklands in Cacheu region contain a great diversity of tree and shrub species. The floral procession consists of 75 woody species divided into 63 genera from 25 botanical families (Table 1). The most represented families are the Fabaceae, Apocinaceae, Moraceae, Combrétaceae and Anacardiaceae with values equal to $24 \%, 9 \%, 8 \%, 6 \%$ and $5 \%$ of the individuals inventoried respectively. These are mainly species with a high capacity for regeneration and which produce new releases after human activity such as land clearing

Table 1. Floral procession of Elaeis guineensis parklands.

\begin{tabular}{lll}
\hline Species & Family & Frequency of presence \\
\hline Adansonia digitata L. & Bombacaceae & 1.45 \\
Afzelia Africana Smith ex pers. & Fabaceae & 1.45 \\
Albizia adianthifolia (Schumach.) & Fabaceae & 26.09 \\
Albizia lebbeck (L.) Benth. & Fabaceae & 7.25 \\
Albizia zygia (DC.) J. F. Macbr. & Fabaceae & 46.38 \\
Alchornea cordifolia Schumach. Et Thonn. & Euphorbiaceae & 37.68 \\
Allophyllus africanus P. Beauv. & Sapindaceae & 47.83 \\
Alstonia booneiDe Wild & Apocynaceae & 4.35 \\
Anacardium occidentale L. & Anacardiaceae & 100 \\
Annona senegalensis Pers. & Annonaceae & 11.59 \\
Anthocleista nobilis G. Don & Gentianaceae & 15.94 \\
Anthostema senegalense A. Juss. & Euphorbiaceae & 20.29 \\
Antiaris africana Lesch. & Moraceae & 1.45 \\
Azadirachta indica Hutch. & Meliaceae & 1.45 \\
Bombax costatum Pellegr. \&Vuillet & Malvaceae & 1.45 \\
Borassus akeassii Mart. & Arecaceae & 15.94 \\
\hline
\end{tabular}




\begin{tabular}{|c|c|c|}
\hline Species & Family & Frequency of presence \\
\hline Carapa procera $\mathrm{DC}$. & Meliaceae & 2.90 \\
\hline Cassia alata (L.) Roxb & Fabaceae & 2.90 \\
\hline Cassia sieberiana Del. & Fabaceae & 47.83 \\
\hline Ceiba pentendra $\mathrm{L}$. & Bombacaceae & 2.90 \\
\hline Cephaelis peduncularis (Schnell) & Rubiaceae & 27.54 \\
\hline Cnestis ferruginea DC. & Connaraceae & 66.67 \\
\hline Cola cordifolia (Cav.) & Malvaceae & 2.90 \\
\hline Combretum micranthum G. Don & Combretaceae & 39.13 \\
\hline Combretum paniculatum (vent,) & Combretaceae & 26.09 \\
\hline Combretum racemosum P. Beauv. & Combretaceae & 1.45 \\
\hline Daniellia oliveri wild & Fabaceae & 1.45 \\
\hline Detarium microcarpum (J. F. Gmelin) & Fabaceae & 18.84 \\
\hline Dialium guineense (Willd) & Fabaceae & 62.32 \\
\hline Dichrostachys cinerea (Wight et Arn.) & Fabaceae & 55.07 \\
\hline Ekebergia senegalensis A. Juss. & Meliaceae & 8.70 \\
\hline Elaeis guineensis (Jacq.) & Arecaceae & 100 \\
\hline Erythrina senegalensis L. & Fabaceae & 4.35 \\
\hline Erythrophleum guineense G. Don & Fabaceae & 8.70 \\
\hline Erythrophleum suaveolens (Guill. \&Perr.) & Fabaceae & 5.80 \\
\hline Fagara zanthoxylum (L.) Sarg. & Rutaceae & 28.99 \\
\hline Ficus elastica (Roxb. ex Hornem.) & Moraceae & 1.45 \\
\hline Ficus exasperata (Vahl) & Moraceae & 1.45 \\
\hline Ficus sur (Forssk.) & Moraceae & 50.72 \\
\hline Ficus sycomorus $\mathrm{L}$. & Moraceae & 2.90 \\
\hline Ficus vogelii (Miq.) & Moraceae & 5.80 \\
\hline Guiera senegalensis J. F. Gmel & Combretaceae & 4.35 \\
\hline Hibiscus sterculiifolius (Guill. \&Perr.) & Malvaceae & 40.58 \\
\hline Holarrhena floribunda (G. Don) & Apocynaceae & 47.83 \\
\hline Khaya senegalensis (Desr.) & Meliaceae & 28.99 \\
\hline landolphia dulcis (Sabine ex G. Don) & Apocynaceae & 60.87 \\
\hline Landolphia heudelotii (P. Beauv.) & Apocynaceae & 47.83 \\
\hline Landolphia owariensis (P. Beauv.) & Apocynaceae & 2.90 \\
\hline Lophira lanceolata Van Tiegh. ex Keay & Ochnaceae & 4.35 \\
\hline Macrosphyra longistyla (DC.) & Rubiaceae & 46.38 \\
\hline Malancantha alnifolia (Bak.) Pierre & Sapotaceae & 63.77 \\
\hline Mangifera indica (L.) & Anacardiaceae & 5.80 \\
\hline Markhamia tomentosa (Benth,) & Bignoniaceae & 8.70 \\
\hline Mimosa pigra $\mathrm{L}$. & Mimosaceae & 10.14 \\
\hline Morinda geminata (DC.) & Rubiaceae & 8.70 \\
\hline Neocarya macrophylla (Sabine) & Chrysobalanaceae & 4.35 \\
\hline Newbouldia leavis (P. Beauv.) & Bignoniaceae & 20.29 \\
\hline Oxytenanthera abyssinica (A. Rich.) Munro & Poaceae & 2.90 \\
\hline Parinari excelsa (Sabine) & Chrysobalanaceae & 21.74 \\
\hline Parkia biglobosa (Jacq.) & Fabaceae & 8.70 \\
\hline Piliostigma thonningii (Schum.) & Fabaceae & 11.59 \\
\hline Prosopis africana (Guill. \&Perr.) & Fabaceae & 15.94 \\
\hline Pterocarpu serinaceus (Poir.) & Fabaceae & 18.84 \\
\hline Raphia vinifera $\mathrm{A}$. Chev. & Arecaceae & 4.35 \\
\hline Saba senegalensis (A. DC.) & Apocynaceae & 50.72 \\
\hline Sarcocephalus latifolius (Sm.) & Rubiaceae & 62.32 \\
\hline Sorindeia juglandifolia (A. Rich.) & Anacardiaceae & 47.83 \\
\hline Spondias monbin L. & Anacardiaceae & 20.29 \\
\hline Strychnos spinosa Lam. & Logaminaceae & 37.68 \\
\hline Tephrosia purperea Pers. & Fabaceae & 33.33 \\
\hline Terminalia macroptera (Guill. \&Perr.) & Combretaceae & 17.39 \\
\hline Uvaria chamae (P. Beauv.) & Annonaceae & 42.03 \\
\hline Vitex doniana (L.) & Lamiaceae & 5.80 \\
\hline Voacanga africana (Stapf ex Scott-Elliot) & Apocynaceae & 1.45 \\
\hline Zanthoxylum zanthoxyloides (Lam.) & Rutaceae & 18.84 \\
\hline
\end{tabular}


However, the distribution of species in palm groves is not homogeneous throughout the region. It varies from one site to another. The distribution of species according to the different sites is shown in the Figure 2.

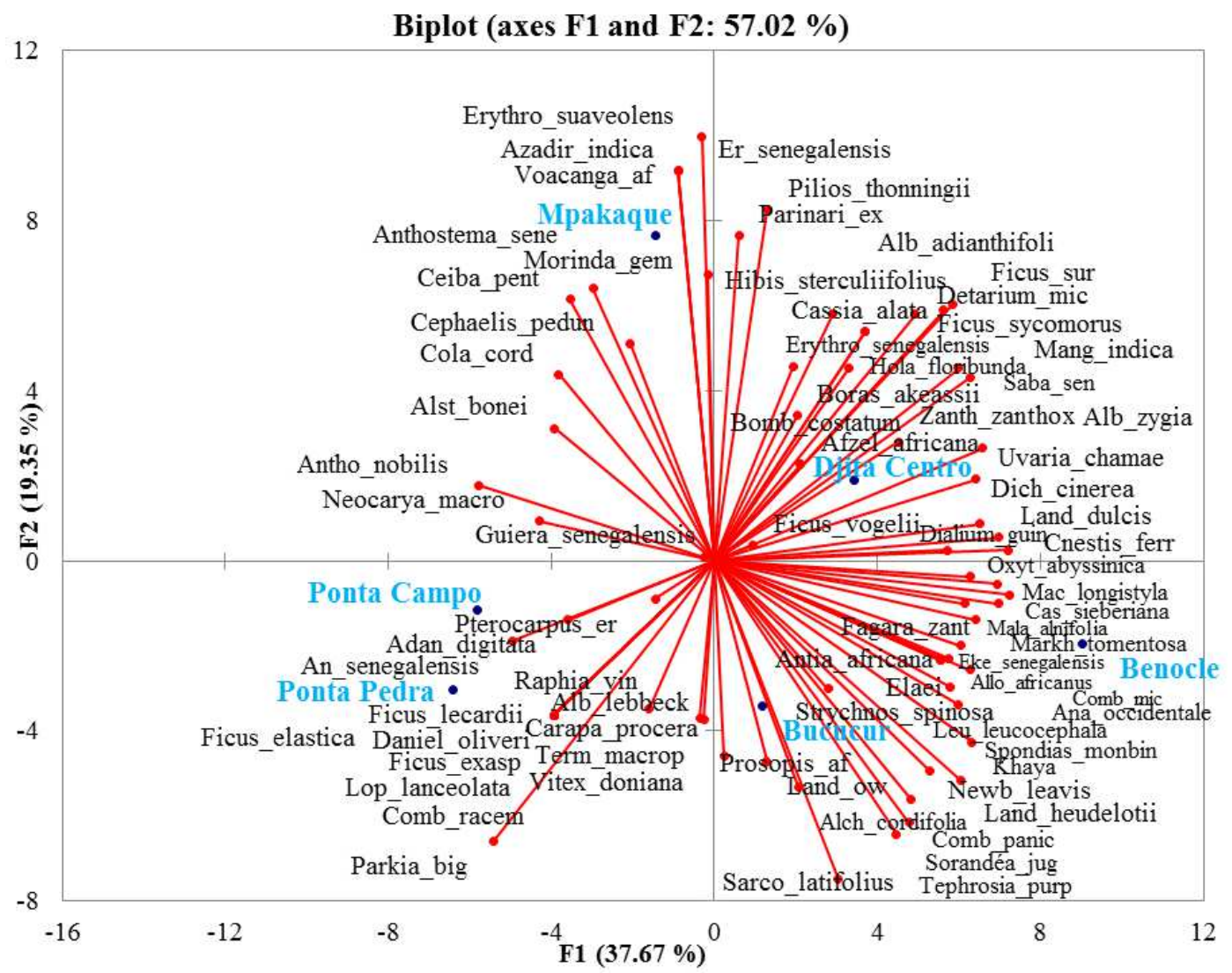

Figure 2. The distribution of species according to the different sites.

The figure 2 shows the distribution of species in the study area. It found similarities between the different sites according to their geographical location. Indeed, the same species are found in sites belonging to the same sector. Species are more common in the villages of Benocle and Bucucucur in the Cacheu area. In the villages of Djitacentro and Mpakaque belonging to the Canchungo sector, there is a fairly regular representation of species, unlike in the Caio sector (Ponta Pedra and Ponta Campo villages) where few species are represented.

\subsection{Structural Parameters of Elaeis Guineensis Parklands}

Data from vegetation surveys carried out at the various sites made it possible to calculate a number of structural parameters for the woody vegetation of palm groves in the Cacheu region. The parameters calculated and the results obtained are recorded in Table 2 .

Table 2. Structural parameters of woody vegetation in palm groves.

\begin{tabular}{ll}
\hline Structural parameters & Value \\
\hline Total specific richness & 75 Species \\
Density of $E$. guineensis & 775 Individuals/ha \\
Density of $E$. guineensiswithout regeneration & 123 Individuals $/$ ha \\
Basal area of $E$. guineensis & $9,24 \mathrm{~m}^{2} / \mathrm{ha}$ \\
Canopy cover of $E$. guineensis & $48,07 \%$ \\
Shannon Diversity Index & $3,14 \mathrm{Bits}$ \\
\hline
\end{tabular}

\begin{tabular}{ll}
\hline Structural parameters & Value \\
\hline Piélou Evenness Index & 0,50 \\
Specific importance of regeneration of $E$. guineensis & $27,62 \%$ \\
Mortality rate of $E$. guineensis & $15,97 \%$ \\
Anthropization rate of $E$. guineensis & $23,35 \%$ \\
\hline
\end{tabular}

a) Specific richness and diversity

Elaeis guineensis parklands in the Cacheu region have a significant specific richness. Indeed, 75 woody forest species have been recorded in the parklands with an average of 17 species /survey. This specific wealth important is explained by the wide distribution of parklands, which affects different landscape units, namely the plateau area, the transition area and sometimes part of the rice field areas. However, specific richness alone, which is the total number of species in a stand, is not sufficient to compare the specific diversity of two stands. For this purpose, the Shannon diversity index was calculated. This takes into account not only the specific richness but also the abundance of each species and is independent of the sample size. Considering this parameter, Elaeis guineensis parklands in the region are moderately diversified with Shannon diversity index of 3.14 bits and Piélou Equitability Index, which reflects the degree of diversity achieved compared to the theoretical maximum of 0.5 . This means that despite the large number of species, the stand is slightly dominated by some species. These are mainly Elaeis guineensis and Anacardium occidentale, a 
planted species that gradually takes over from spontaneous vegetation because of its monetary value. Indeed, in almost all palm groves, there are young cashew plantations with a high density.

b) Density

The density of Elaeis guineensis in the parklands is very high. It is estimated at 775 individuals/ha compared to 1587 individuals/ha for other cumulative species. However, a large majority of these palms are made up of regenerations. Indeed, the real density of Elaeis guineensis without regeneration is 123 individuals/ha.

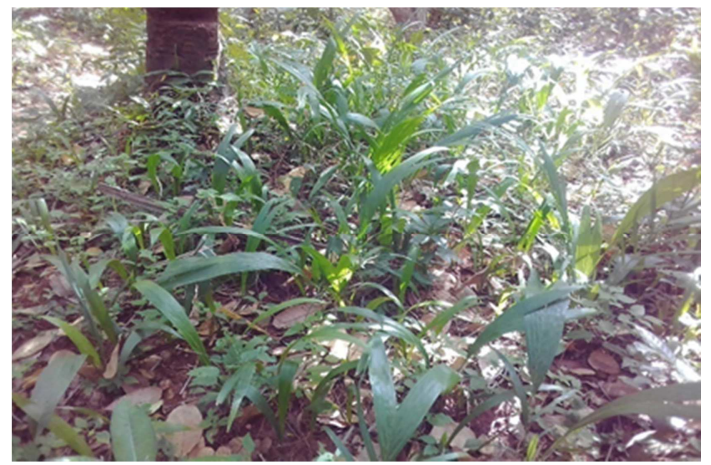

Figure 3. Elaeis guineensis regeneration.

c) Basal area and canopy cover of Elaeis guineensis

The basal area is the anchoring area in $\mathrm{m}^{2} /$ ha estimated at $1.30 \mathrm{~m}$ from the tree trunk. It is estimated at $9.24 \mathrm{~m}^{2} / \mathrm{ha}$. The woody cover is the surface of the crown of the tree projected vertically to the ground; it indicates the surface covered by the foliage of the tree. The table shows that the parklands are fairly covered with a recovery rate of $48.07 \%$ for Elaeis guineensis. These values are slightly lower than those found by [24] in the Elaeis guineensis parklands at in Lower Casamance.

\section{d) Natural regeneration}

Natural regeneration is the basis for understanding the dynamics of woody vegetation. It can be vegetative or by natural sowing. It involves recruitment, child mortality and the different stages of development, then survival [20]. In palm groves, stand regeneration was assessed by the importance of the young plants. The analysis of the table shows that the specific regeneration importance of Elaeis guineensis is important $27.62 \%$. There is also a very high number of regeneration of Anacardium occidentale with a value of $12.63 \%$. However, almost all palm regrowth does not reach adulthood.

e) Mortality rate and anthropization index

Analysis of mortality and anthropization degree reveals significant pressure on Elaeis guineensis in the region. This is marked by a relatively high mortality and anthropisation rate of $15.97 \%$ and $23.35 \%$ respectively. And as the vegetation surveys were carried out in November, the value of the anthropisation index will be much higher than that of January and February, which correspond to the period of intense palm wine harvesting. Mortality and anthropization factors are mainly related to palm tree cutting for house construction and for the establishment of Anacardium occidentale plantations, pruning of leaves for wine harvesting or other uses and fires during field cleaning.
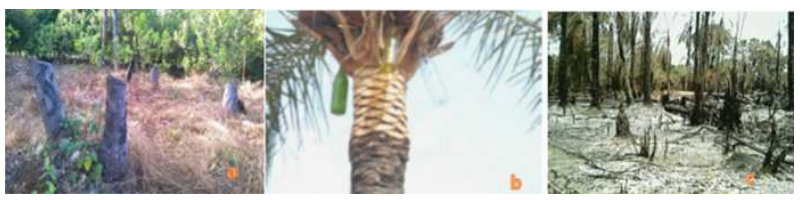

Figure 4. Facteursd'anthropisation des parcs à Elaeis guineensis: (a) tree cutting, (b) exploitation of palm wine, (c) conversion of spaces.

The structural parameters are not homogeneous over the entire region. They vary from one site to another epending on soil, topographical and anthropogenic factors mainly related to cultural practices. The PCA carried out on the basis of the calculated values made it possible to characterize the different sites according to the structural parameters. The results obtained are shown in Figure 5, which shows a total inertia of $71.16 \%$ (39.95\% for axis $\mathrm{F} 1$ and $31.21 \%$ for axis $\mathrm{F} 2$ ), which is sufficient to get the most information.

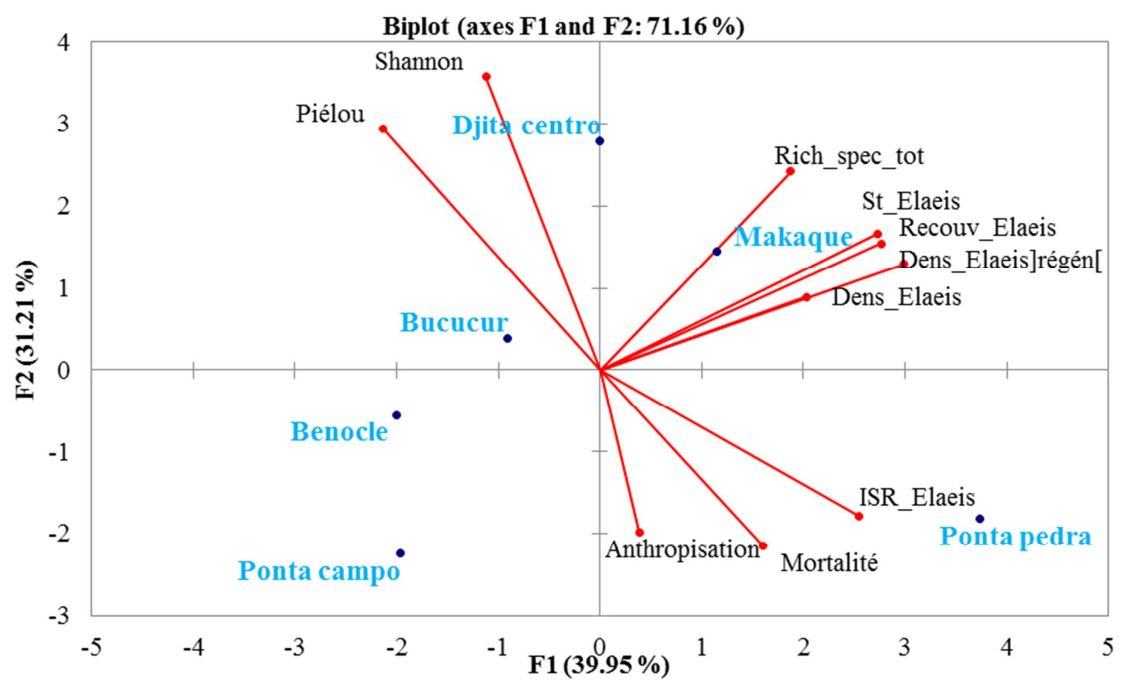

Figure 5. Characterization of the different sites according to structural parameters. 
The analysis of the Figure 5 shows that the palm groves of the village of Mpakaque have a significant specific richness but are slightly dominated by certain species. They are also characterized by a high real density of Elaeis guineensis resulting in a high basal area and a high overlap, unlike the palm groves of the villages of Ponta Campo and Benocle, which have low values for these parameters. In the latter two villages, palm groves are located more in plateau areas, unlike others where they are mainly located in transitional areas characterized by a high specific wealth. In Ponta Pedra, despite a specific importance of Elaeis guineensis high the presence of a significant number of palm regeneration, the survival of the species is relatively problematic. Indeed, we notice a pressure on the palm tree materialized by a high mortality and anthropization rate in this village. In the parklands of Djitacentro, there is a fairly high specific diversity and a certain equity in the distribution of these species.

\subsection{Vertical Structure of Elaeis Guineensis}

The individuals of Elaeis guineensis measured during vegetation surveys were divided into height classes ranging from 0 to more than 18 with a 3 step. The results obtained are shown in Figure 6.

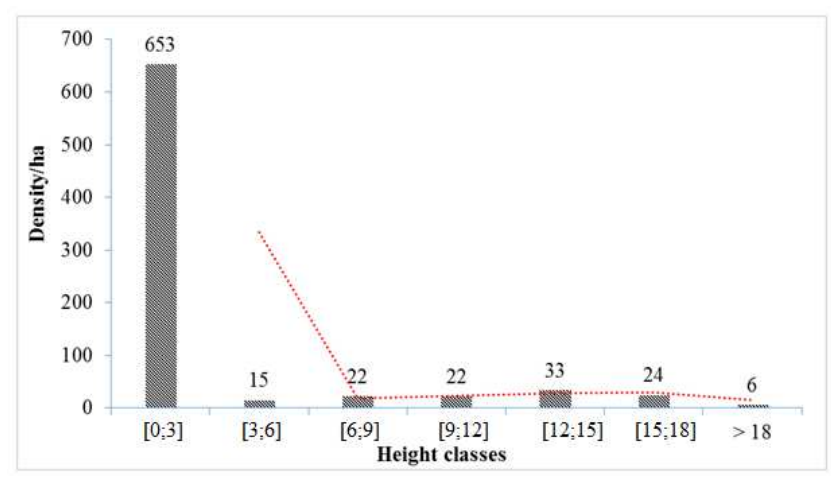

Figure 6. Elaeis guineensis vertical structure.

Elaeis guineensis distribution according to height shows that most of the individuals encountered have a size between 0 and $18 \mathrm{~m}$. However, the class $[0,3]$ is largely dominant with densities of 653 individuals/ha. This high density of young palm trees under $3 \mathrm{~m}$ hides the reality of the terrain. Indeed, $91.55 \%$ of the individuals in this class are young shoots less than $60 \mathrm{~cm}$ tall. This height class is followed by classes [12, $15,18]$ with densities equal to 33 and 24 individuals/ha respectively. Classes $[6,9,12]$ are moderately represented with 22 individuals/ha each. Individuals from 3 to 6 meters are few in number (about 15 individuals/ha). This reveals the difficulty of regenerating plants to grow normally. Indeed, the latter are often cut by landowners during the preparatory clearings of the cashew campaign, buried during ploughing or suffocated by excessive shade in Anacardium occidentale plantations.

\subsection{Horizontal Structure}

The collected data also made it possible to distribute Elaeis guineensis individuals whose trunk height is greater than $1.3 \mathrm{~m}$ according to their diameter. The results obtained are shown in the Figure 7.

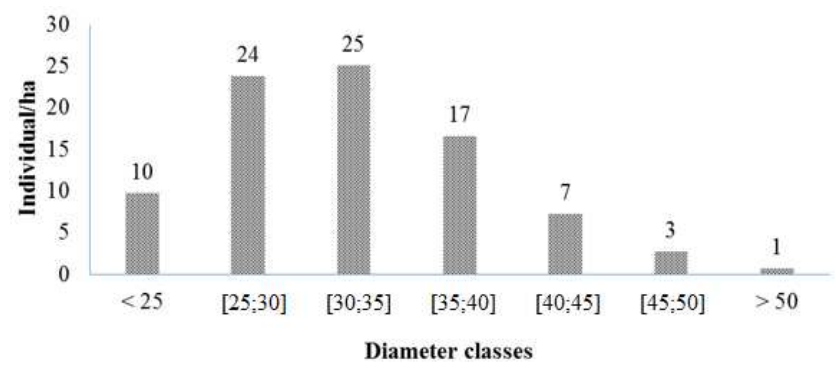

Figure 7. Horizontal structure Elaeis guineensis.

The Figure 7 shows that most of the individuals of Elaeis guineensis measured have a diameter between 20 and $50 \mathrm{~cm}$. However, the diameter classes [30, 35, 25, 30] have more individuals with values equal to 25 and 24 individuals/ha respectively. They are followed by the class [35, 40] and subjects with diameters less than $25 \mathrm{~cm}$. It is necessary to note that diameter is not an indicator of age in Arecaceae because it is a parameter that changes differently from one subject to another. In some young individuals of Elaeis guineensis, the diameter is very developed but decreases as they grow, while in others it is the opposite.

\section{Discussion}

Elaeis guineensis agroforestry parklands in the Cacheu region contain a great diversity of woody species, most of which belong to the Fabaceae family. This family, more traditionally called legumes, represents a very large family that includes trees, annual or perennial herbaceous plants, vines and even aquatic plants. Fabaceae are of great importance in human life, as they are a first-rate food source. Fabaceae are also a source of oil, green manure, fodder, some species produce wood or natural dye, etc. This diversity of species in the parklands has been noted by several authors such as $[3,12,24]$ who have demonstrated, through studies carried out in Benin and Lower Casamance, that in Elaeis guineensis agro systems, in addition to oil palm, there are several valuable indigenous species such as Adansonia digitata, Albizia spp, Vitex doniana, etc. The distribution of these species accompanying Elaeis guineensis differs according to the different geographical areas. This disparity in the distribution of species within palm groves according to different geographical sub-areas has also been noted by $[9,7]$ in the palm groves of Lower Casamance.

The actual density of Elaeis guineensis in the parks appears to be very high in the parks of the region. However, the overwhelming majority are young regenerators, most of whom are not reaching adulthood. These results corroborate those of $[6,7]$ who encountered a similar situation in the 
palm groves of Lower Casamance. According to these authors and [11], young individuals from regeneration are under strong pressure due to poor agricultural practices and other human activities, which prevents them from reaching adulthood, thus weakening agroforestry parklands in Elaeis guineensis. Adult subjects are not spared from this pressure. They are victims of poor agricultural practices marked by a gradual conversion of natural ecosystems into Anacardium occidentale orchards, intense cuts to house construction and poor palm wine production practices. This is what justifies the relatively high values of mortality and anthropization rates in the parklands. This pressure on these parks is also reported in Lower and Middle Casamance by $[12,15,16]$ who reported an over-exploitation of the species in this area.

\section{Conclusion}

The Cacheu region covers important natural palm groves that are of vital importance to the local population. The characterization of these palm groves carried out through this study has revealed a number of problems affecting these ecosystems. This is the phenomenon of ageing fleets linked to a renewal problem. In addition, the fact that the parks are under relatively high human pressure, marked by a very high mortality and anthropization rate. These combined factors show a certain fragility of the Elaeis guineensis agroforestry parklands in the Cacheu's region. In view of the importance of these parklands in the daily lives of the region's populations, it is imperative to ensure the sustainability of these production systems through the enhancement and sustainable use of the region's natural palm groves, the guarantee of parkland renewal through Assisted Natural Regeneration (ANR) techniques, and the respect of a reasonable equidistance with Anacardium occidentale plants.

\section{Acknowledgements}

This study was carried out within the framework of a partnership between the Groupe de recherché et de realizations pour le développement rural (Grdr) and the Assane SECK University of Ziguinchor. This partnership is part of the broader framework of the Coastal Concerted Governance Program (PGCL). We would also like to thank institutions such as the Laboratory of Plant Ecology of the University Cheikh Anta Diop of Dakar and the Regional Inspectorate of Water and Forests, Hunting and Soil Conservation of Ziguinchor for their collaboration in the realization of the study. We also thank the populations of the villages chosen for the study for the reception, their availability, their collaboration during the collection of the data.

Our gratitude to Ndiouga Sarr BADJI and René Joachim MANGA, students at the Centre National de Formation des Techniciens de Eaux et Forêtsfor their technical support during the realization of vegetation surveys.

Our thanks go to our relatives and friends for their moral support.

\section{References}

[1] Akpo L. E. \& Grouzis M. 1996. Influence du couvert ligneux sur la régénération de quelques espèces ligneuses sahéliennes (Nord Sénégal, Afrique occidentale). Webbia, 50 (2), 247-263.

[2] Akpo L. E, Coly I, Sarr D, Ngom D, Ndao S. 2004. Mode d'utilisation des terres et diversité floristique dans le terroir de Néma en zone semi-aride (Sénégal, Afrique de l'Ouest). J Agric Environ Int Dev 98: 165-18.

[3] Akouehou G. S., Assogba D. O., Houndonougbo A. et Sinsin A. B. 2013. Diversité floristique, sécurisation foncière et gestion des systèmes agroforestiers à palmier à huile (Elaeis guineensis) en zones périurbaines et rurales du Département de l'Atlantique au Sud du Bénin. ISSN 1991-8631. 10 pages.

[4] Arvanitis Y. 2014. Ressources naturelles en Guinée-Bissau: partir du bon pied. 56 pages.

[5] Banjai B. B. 2009. Quatrième Rapport National sur la Diversité Biologique, 99 pages.

[6] Camara B. 2018. Caractérisation agro-écologique et socioéconomique des parcs agroforestiers à Elaeis guineensis Jacq. Et Faidherbia albida (Del.) Chev. et leurs influences sur la productivité du riz pluvial en basse Casamance (SENEGAL) Thèse de Doctorat en Agroforesterie, EDSTI/ Université Assane SECK /Ziguinchor, 153 pages.

[7] Camara B., Gosme M., Ngom D., Gomis Z. D., Badji M., Sanogo D. et Dupraz C. 2018. Ecological characterization and evolution of Elaeis guineensis Jacq. traditional parklands in Lower Casamance (Senegal). Agroforest Syst. Received: 7 February 2017 / Accepted: 24 April 2018 https://doi.org/10.1007/s10457-018-0237-3.

[8] Dan Guimbo I., Mahamane A. et. Ambouta K. J. M. 2010. Peuplement des parcs à Neocarya macrophylla (Sabine) Prance et à Vitellaria paradoxa (Gaertn. C. F.) dans le sudouest nigérien: diversité, structure et régénération Int. J. Biol. Chem. Sci. 4 (5): 1706-1720.

[9] Diatta E. A. et Sagna B. 2013.-Caractérisation et modes d'exploitation des parcs à Elaeis guineensis, Jacq. en Basse Casamance: cas des villages de Carounate (cassa) et de Djiguinoume (kalounayes). Mémoire de Licence Agroforesterie, Université Assane de Ziguinchor. 49 pages.

[10] Diedhiou M. A. A., Faye E., Ngom D., Touré M. A. 2014. Identification et caractérisation floristiques des parcs agroforestiers du terroir insulaire de Mar Fafaco, Sénégal. Journal of Applied Biosciences 79: 6855-6866 ISSN19975902 .

[11] Gbesso F., Yedomonhan H., Tenté B., Akoegninou A. 2014. Distribution géographique des populations de rôniers (Borassus aethiopum Mart, Arecaceae) et caractérisation phytoécologique de leurs habitats dans la zone soudanoguinéenne du Benin. Journal of Applied Biosciences 74: 6099 $-6111$.

[12] Gomis Z. D. 2014. Les parcs agroforestiers à Elaeis guineensis Jacq. (Palmier à huile): Caractéristiques biophysiques et importance socio-économique à Ouonck (Basse-Casamance). Mémoire de Master 2. Université Assane de Ziguinchor. 79 pages. 
[13] Grall, J., Coïc, N. 2006. Synthèse des méthodes d'évaluation de la qualité du benthos en milieu côtier. REF. Ifremer DYNECO/VIGIES/06-13/REBENT. 91 pages.

[14] Gray, J. S., McIntyre, A. D., \&Stirn J. 1992. Manuel des méthodes de recherche sur l'environnement aquatique. Onzième partie. Evaluation biologique de la pollution marine, eu égard en particulier au benthos. FAO Document technique sur les pêches, $\mathrm{N}^{\circ} 324,53.46,151-165$.

[15] Gueye, S. 2000. Etude sur les ressources forestières et les plantations forestières du Sénégal, Période 1992-99, 61 pages.

[16] Ilboudo J. B. et Sambou B. 1991. Facteurs de dégradation et restauration des palmeraies, séminaire atelier sur les barrages anti-sel et l'aménagement des terres basses. 59 pages.

[17] Lebailly, P. et Tentchou, J. 2009. Étude sur la filière porteuse d'emploi « palmier à huile». Ministère. de la Formation Professionnelle et Organisation Internationale du Travail. 83 pages.

[18] Ngom D., Diedhiou A. A., Akpo L. E., Mbaye T., Charahabil M. M., Camara B., Gomis Z. D., et Sagna B. 2015. Les parcs agroforestiers traditionnels: caractéristiques écologiques et influences sur la riziculture pluviale en zone post-conflit de la Basse Casamance. Projet Banque Mondiale. 22 pages.

[19] Ngom D., Camara B., Sagna B. et Gomis Z. D. 2018. Cortège floristique, paramètres structuraux et indicateurs d'anthropisation des parcs agroforestiers à Elaeis guineensis Jacq. en Basse Casamance, Sénégal. Journal of Animal \&amp; Plant Sciences, 2018. Vol. 36, Issue 3: 5919-5932 Publication date 30/06/2018, http://www.m.elewa.org/JAPS; ISSN 20717024.

[20] Ngom, D. 2014. Perceptions communautaires sur les services écosystèmiques d'approvisionnement fournis par le peuplement ligneux de la réserve de Biosphère du Ferlo (Sénégal). Vertigo- la revue électronique en science de l'environnement Volume 14 Numéro 2 (septembre 2014) Varia. 17 pages.

[21] Poupon H. 1980. Structure et dynamique de la strate ligneuse d'une steppe sahélienne au Nord du Sénégal. - ORSTOM, Paris, 351 pages.

[22] Pichette R. et Gillespie P. L. 2002. Protocoles de suivi de la biodiversité végétale terrestre, Musée canadien de la nature Ottawa, Canada, URL: http:///www.eman-rese.ca.

[23] Ramade F. 2003. Ecologie: Eléments d'écologie fondamentale. 3ème édition, Dunod, Paris; 690 pages.

[24] Sagna B. 2016. Paramètres structuraux, modes de gestion et importance socioéconomique des parcs agroforestiers à Elaeis guineensis Jacq. (Palmier à huile) en Basse Casamance. Mémoire de Master 2. Université Assane SECK de Ziguinchor. 55 pages. 